\title{
Impact of Restaurant Attributes on Customer Perceived Value and Customer Satisfaction: Special Reference to Beach Restaurants in Southern Coastal Area, Sri Lanka
}

\author{
C.P. Danthanarayana ${ }^{1 *}$ and R.S.S.W. Arachchi ${ }^{2}$ \\ ${ }^{1 *}$ Department of Management Studies, University College of Matara, Matara, Sri Lanka \\ ${ }^{2}$ Department of Tourism Management, Sabaragamuwa University of Sri Lanka, Belihuloya, Sri \\ Lanka
}

\begin{abstract}
Despite its popularity, the concept of customer satisfaction in the service industry in the marketing literature is still able to examine. The significant growth of the restaurant industry has made a strong contribution to the food and beverage sector in the hospitality industry. Modern customers are expecting broad experience from restaurants beyond food and beverages. Hence beach restaurants have been popularized all around the world. However, satisfying the customers has become challenging in the service sector like restaurant industry due to the high competition. It is essential to maintain particular attributes to create customer perceived value and ultimately satisfy the customers. This study was conducted to identify the impact of restaurant attributes on customer perceived value and customer satisfaction specifically in the beach restaurants in Southern coastal area in Sri Lanka. 385 tourists who fulfilled their dining requirements at the beach restaurants in the Southern coastal area were selected using a convenient sampling technique and a self-administered questionnaire was fielded to collect primary data. Mediator analysis has conducted through Structural Equation Modelling (SEM) technique and SmartPLS software has used to analyse data. Five underlying factors were analysed under restaurant attributes; of food and drink related attributes, ambience and atmosphere related attributes, price related attributes, location and place related attributes, and service-related attributes. The results reveal that the perceived value has a potential to be fully mediating variable between restaurant attributes and customer satisfaction in beach restaurants. Service providers of beach restaurants can enhance the uniqueness of restaurant attributes to enhance customer perceived value and ultimately it will enhance customer satisfaction as well.
\end{abstract}

Keywords: satisfaction; perceived-value; restaurant attributes; tourists, beach restaurants

\section{Introduction}

In the economy of any country, service sector is playing a vital role. Therefore, to become more competitive, organizations are searching different ways to become more unique and differentiate themselves from their rivals. Customer satisfaction is driving the value creation in customer experience, anticipating and managing customer expectations and representing firm's ability to fulfil customers' requirements. With the aim of achieving the customer satisfaction, firms required to identify and properly forecast customer needs and it will gain more revenue for the company (Barsky \& Nash, 2003). Cost of retaining current customers are lessor than attracting new potential customers. Therefore, owners of the organizations must emphasis on retaining current customers by implementing better policies to make more satisfied customers and enhance their loyalty. This will apply into hospitality industry in a vital way since it is under the umbrella of service industry. It is a biggest challenge for owners and managers in hospitality industry to sustain customer satisfaction. As per the past researches quality products and services has become more important in tourism and hospitality industry ( $\mathrm{Su}, 2004)$ and with the importance to achieve customer satisfaction is one of the key objectives of any business (Barsky \& Nash, 2003). As discussed above, customer satisfaction leads to customers' commitment to retain within the hotels, and maintaining the long term customer relationship with customers resulting competitive advantages for the hotel (Choi \& Chu, 2001).

Eating out in restaurants offers a relaxation and enjoyment from the gathering of the members of family, friends, peers and business associates (Walker, 2014). Restaurant sector is satisfying the unfulfilled human need of hunger and social need of togetherness. Therefore, restaurant industry has become competitively emerging business worldwide. 
According to the past researchers (Omar et al., 2014), restaurants are playing a most important role in social activities in customers' lifestyle. It is very important to understand the concepts of restaurants to enhance the competitiveness and restaurant image among customers. Concept of the restaurant is enhancing the attention of customers towards the restaurant in selection and evaluation the customer experience at restaurants. To become successful restaurant business, ambience, restaurant décor, restaurant design, food, beverages, cultural artifacts and entertainment should be given more attention by the restaurant owners (Omar et al., 2014).

There are 503 registered restaurants under Sri Lanka Tourism Development Authority (SLTDA) and there are large number of unregistered restaurants established within the country and contributing to provide hospitality services for local and international travelers. Beach restaurants are very famous type of restaurants in Sri Lanka. Since most of the tourists $(83.2 \%)$ visited Sri Lanka for the leisure purpose (SLTDA, 2019), mostly they are gathering to the leisure sites and coastal areas around the country. Therefore, it can be seen huge demand for beach restaurant from leisure travelers. South coast is having highest number of accommodation facilities as well as 49 SLTDA registered and many more unregistered destination restaurants (beach restaurants) in South Coast, Sri Lanka. Therefore, researcher selected beach restaurants in South coast to conduct the research study.

As customer satisfaction is a substantial predictor of post - consumption behaviour of customers, it is a key element of customers' repeat sales, loyalty and word-of-mouth intention (Anderson \& Sullivan, 1993). Hotels are improving their focus to enhance quality of the service and perceived value of customers to achieve customer satisfaction. Perceived value is also having high association with service quality, food quality and physical environment and customer satisfaction. However, in past researches, the role of perceived value is relatively unexplored in service marketing (Ryu et al., 2011). Trade-off between perceived benefits and perceived sacrifices can be considered as perceived value according to the past studies (Ryu et al., 2011).

\section{Problem Justification}

Generally, food consumers are searching more secure, hygienically safe, delicious foods which are offered by neatly and well-dressed food servers working in well-established restaurants. According to the Clark \& Wood (1999), they confirmed that food quality is a primary factor influencing customer satisfaction and loyalty in restaurant choice. Ryu et al (2011) persisted that from the customer's perspective, food quality is a key determinant for visiting a restaurant. A customer will judge a restaurant based on several areas: food quality and presentation, service, ambiance, cleanliness and value (Wade, 2006). However, they also considered food portion, menu variety, reasonable cost, and healthy food options as valuable factors (Jang \& Ha, 2009). The notable thing is that many restaurant customers are interested in their health, thus, the availability of nutritious food items has become increasingly important as one of the core properties of dining satisfaction (Sulek \& Hensley, 2004).

Previous studies have identified atmospherics as another important element of the dining experience and reported that atmospherics influence customer's emotions and expectations regarding service and food quality (Wall \& Berry, 2007). Usually, a customer first perceives the atmospherics when he or she enters a restaurant, which occurs before any actual services or foods are delivered. Thus, the emotions created by the perception of the atmospherics may affect the customer's reaction to the actual services and foods in restaurants (Zeithaml et al., 1993). In addition, Ryu et al, (2011) pointed out that consumer's perception of a restaurant's image will return customer's cumulative consumption such as food, atmospherics, and service. That is, if a customer has a high perception of the atmospherics, then customers' expectations for service and food quality could also be higher.

Based on the preliminary study conducted by the researcher, there is a huge demand for beach restaurants as dinning location than other fast food restaurants, theme restaurants, hotels, pubs, street food vendors and other meal providers. Researcher required to identify the influence of above mentioned attributes which are applicable in restaurant sector in general on customer satisfaction in beach restaurants. With the observation in the preliminary study, researcher has identified beach restaurants are not following proper standards, safety measures, hygienic conditions and maintain clean atmosphere at the restaurants compared with other type of restaurants. Food servers are not wearing standard type of uniforms and maintain good attire when serving food and beverages. Moreover, the researcher conducted some 
interviews with tourists as well as service providers at beach restaurants to get some background knowledge regarding the research area. According to the customers;

Even though in these restaurants have not a standard service, proper uniforms for employees, hygienically safe foods than star class restaurants guests love to be with the local settings to get the unique restaurant experience at beach restaurants.

"We love to be here to get our meals and local settings even though they don't have standard service" (Tourist 1 , personal communication, February 08, 2019).

Generally British tourists are considering high standards at the dinning location, proper dinning etiquettes and hygiene. However, they also love to experience the local values and physical settings of beach restaurants than what they are expecting traditionally.

"Dinning at beach restaurant is totally different and live experience than dinning at a hotel, because of the location and environment. And if we want to see the chicken dish preparation process from supplying raw chicken to the final dish, we can't get that experience. But here we can see whole process at one single place" (Tourist 2, personal communication, February 08, 2019)

According to that customers' view they love to get live experience of fishing, supplying of raw fish for preparation, seafood meal preparation and serving at the same time at beach restaurants.

"We are staying at luxury hotel. But at our hotel we can't get the experience of eating foods at this kind of setting. Even though we have half board basis at our hotels, we just skip that meal and come here to get meals" (Tourist 3, personal communication, February 08, 2019).

It is difficult to compare beach restaurants and star class hotels under the same category based on the service. However, customers are willing to have different meal experiences which offered by beach restaurants than traditional star class hotels. According to the service providers;

"We are putting more than 150 tables in the beach within the season, and also sunbeds. Within the season, waves are going back from beach and it has lot of spaces at the beach" (Service provider 1, personal communication, February 08, 2019 beach restaurants).

"More than 10,000 tourists are coming to these restaurants in the season" (Service Provider 2, personal communication, February 08, 2019)

Based on the results and observation of the preliminary study, it has identified a huge demand as well as special attributes of beach restaurants than the other restaurants. Therefore, there should be a relationship with identified attributes and consumer expectation and their satisfaction in beach restaurants. Therefore, researcher hope to identify the relationship between these attributes; food and drink related attributes, ambience and atmosphere related attributes, price related attributes, location related attributes and service-related attributes which have identified by past researchers on consumer perceived value (CPV) as well as customer satisfaction (CS) in beach restaurants by conducting mediator analysis between variables.

There are number of researches based on service quality, return intention and customer satisfaction of the restaurant services. However, there are lack of academic studies in the area of the attributes of restaurants influence the customer satisfaction in beach restaurants. Past research also suggested to examine the relationship between attributes and its influence on customer satisfaction (Ponnam \& Balaji, 2014). Finally, this study assessed the importance of restaurant attributes in beach restaurants. As customer satisfaction is relating with the performance and influences of attributes (Pizam \& Ellis, 1999), it will be interested to investigate how these restaurant attributes are affecting customer satisfaction in beach restaurants. 


\section{Research Objectives}

- To identify the factors which are influencing restaurant attributes in beach restaurants

- To assess the impact of Customer Perceived Value in the relationship between Restaurant Attributes and Customer Satisfaction

\section{Significance of the study}

This research is significant for the service providers to recognize most important factors which are influencing customer satisfaction in beach restaurants. It will apply on tourists' as well as service providers' perspectives. Therefore, this will important to identify different restaurant attributes and most important attributes among them to influence customer behaviour and their satisfaction. Restaurant owners and employees will gain benefits from this study to identify the importance of strategies which can be used by service providers to make customers satisfied in beach restaurants. As marketers it is very important to understand the value of making effective strategies which can impact on the consumer satisfaction. The researcher hopes that the study will benefit the restaurant operators in providing best practices and provide a contribution to the knowledge improvement, useful to the researchers and academician in hotel and restaurant industry. This research will aim to support these benefits in terms of physical attributes, food quality, atmosphere, service quality, location and convenience of restaurants. Furthermore, this research contributes to the literature on hospitality industry. Policy makers in hospitality and tourism industry will be benefited from this study when they are developing different strategies and policies in the industry. They can identify the different restaurant attributes to sharp customer experience and make policies to enhance those attributes. Practitioners will be benefited from the study to identify different managerial implications when they are operating beach restaurants. Through that, they can enhance the customer value as well as the satisfaction within the restaurants.

\section{Literature Review}

\section{Tourism Industry in Sri Lanka and Tourism in South Coastal area, Sri Lanka}

As the third largest foreign income earner in Sri Lanka in 2019, Tourism industry is playing an important role in Sri Lankan economy while providing 173,592 employment opportunities for Sri Lankan job market (SLTDA, 2019). As it is a sensitive industry for the changes of an external environment, it has to face different environmental changes such as 30 years' war, Easter attack and COVID-19 global pandemic in recent past. With the negative effect of Easter attack on 21st April 2019, there is a reduction of 9.2\% in official tourist receipts (Rs. 646,362 million) in 2019 when compared with previous year (SLTDA, 2019). In the year 2019, major source market for Sri Lankan tourism industry is Europe and second major source market is Asia and Pacific (SLTDA, 2019).

Primarily, the traditional Sri Lankan tourism industry has established based on south coast and cultural triangle (Buultjens, et al., 2016). Initially established tourism industry on south coast has focused on mass international tourism based on "Sea, Sun and Sand" concept. With the wonderful coastal line, south coast is providing variety of recreation opportunities among beach destinations, favourable climate, national parks and wildlife and rich cultural heritage (Lai, 2002). Mirissa has become famous whale watching point, Tangalle has become major diving destination, Hikkaduwa and Unawatuna has well established for scuba diving, Weligama has promoted as surfing destination, Galle has become historical archaeological site recognized by UNESCO, Yala and Udawalawa national parks offers wildlife experience, and Kataragama temple and Mulkirigala rock temple creates cultural and religious destination within south coast (Fernando, et al., 2013). All these attractions are creating south coast as wonderful tourist region which enriches with diversity of tourism products and services.

South coast is one of the major regions in Sri Lankan Tourism which covers the districts of Kaluthara, Galle, Matara, and Hambanthota (SLTDA, 2019). According to the SLTDA annual statistical report in 2019, South Coast is holding the highest accommodation capacity as $35.02 \%$ which is greater than Colombo city (22.71\%) and Greater Colombo (12.29\%). When considering the occupancy percentage in accommodation sector, South Coast is creating the highest occupancy rate as 59.7\% (SLTDA, 2019). Moreover, when considering foreign guest nights in graded accommodation 
establishments (Classified / Unclassified / Boutique) in 2019 South coast, it is showing highest number as 3,686,554 including 2,484,436 in up to Galle and 1,202,118 in beyond Galle. Therefore, it is statistically proving that, South coast is playing a significant role in Sri Lankan tourism industry and it is having great demand from international tourists.

\section{Restaurant Attributes (RA)}

Evaluation of RA is generally connecting with the restaurant experience (Ponnam \& Balaji, 2014). These attributes are highly influencing the customers' purchase decision and at the end it will impact to the customers' satisfaction level (Chen \& Hu, 2010). According to the previous researchers, these RA can be divided in to main two elements as; tangible elements (food, layout of the facility) (Chen \& Hu, 2010) and intangible elements (friendliness of the staff, ambience) (Jang et al., 2011) which can be considered when selection and evaluation of restaurant services. These can be depended on the situational factors such as restaurant types and demographic characteristics of the sample.

Han \& Hyun (2009) done the research by using Structural Equation Modelling and identified quality of food and restaurant service, location, price and environment as elements affecting customers' equity in restaurants. Jang et al. (2011) have done the study by using descriptive analysis, factor analysis and cluster analysis for green restaurants and natural ingredients, service value, service reliability, reputation of the restaurant, food quality, nutritional value of the menu items and atmosphere of the restaurant were identified as key RA to differentiate the clusters. Quality of the foods, quality of the service, atmospherics, uniqueness of the atmosphere and food authenticity were identified as key attributes to influence value, emotions of customers' and their behavioural intentions by conducting factor analysis and structural equation modelling (Jang et al., 2012).

Maintaining differentiated restaurant attributes is strategically important task in facing competition for restaurateurs since it has directly influenced on CPV and CS (Rye et al., 2011). These attributes are affecting perceived quality of customers which can be considered as main element in CPV. Moreover these attributes were impacted on firm's reputation on customers' perception towards the products or services (Cretu \& Brodie, 2007). Since perceived reputation also can be considered as key element in CPV, it can confirm the association of these attributes on CPV. Customers who are experiencing favorable restaurant environment with these attributes are getting better CPV and high CS.

Based on the past researchers' findings, researcher has selected food and drink related attributes, ambience and atmosphere related attributes, price related attributes, location related attributes and service related attributes as key RA to develop the independent variable of conceptual framework to conduct the study. Jang et al., 2012 stated that, high quality foods motivates customers to spread the positive words about the experience that they received from dinning at the restaurant. Apart from the food quality, nutritional value of foods (Howlett et al., 2009), menu names (Wansink et al., 2005) and healthy food choice (Namkung \& Jang, 2008) were considered as Food and Drink related attributes (FDA) which are significantly contribute in restaurant evaluation and CS. Ambience and Atmosphere related attributes (AAA) consisting physical, social and ambient dimensions (Ponnam \& Balaji, 2014). Table setting, seat space, restaurant layout, interior design and architecture determines the physical dimension and social dimension includes the customers, other customers and service personnel. Finally ambient dimension consists the atmospheric attributes such as theme, background music, colours, lighting, smell and deco's of the restaurants. These key environmental attributes are influencing customers' emotions and behavioural intentions (Liu \& Jang, 2009). Price related attributes (PA) of the foods and beverages is non-food related element which can be determined and communicated the quality of the restaurant and restaurant experience (Ponnam \& Balaji, 2014). Among the factors such as; brand name, service, hygiene and food related attributes, menu price is having significant importance in selecting decision of restaurant (Baek et al., 2006). As per the literature, location is one of the most important factor for restaurant as retail outlet (Anderson et al., 1997). In the literature, location is highly effective for the fast food restaurants since easy access is important factor for these types of restaurants (Kivela et al., 1999). Past researchers found that, location related attributes (LA) didn't have an impact on CS at restaurants (Haghighi et al., 2012). However, in the tourist's perspective, they were more concerned about the location, convenience and appearance of the restaurant (Yüksel \& Yüksel, 2003). However, when establishing the restaurants, restaurateurs are seeking for 
location alternatives, evaluate them and select best location (Ponnam \& Balaji, 2014). They mentioned that, availability of mass transportation and enough parking facility is mostly related to the restaurants to attract more customers. Restaurant service related attributes (SA) are consisting the interactions of service staff and customers and the evaluation of the service quality is considering as one of the most vital factor in CS in restaurants (Dhurup et al., 2013). Effectiveness of employee service is depending on the employees' willingness to assist the customers, personal attention for customers, quality of the service and employee friendliness and these characteristics are creating positive associations in customers' mind (Dhurup et al., 2013). In restaurant settings, service employees are characterized by reliability, responsiveness, caring, knowledge about the restaurant products and environment, solicited and unsolicited actions (Yüksel \& Yüksel, 2003; Namkung \& Jang, 2008). Positive evaluation of these characteristics and the interaction of customers and employees influence on customers' perception of restaurants' overall quality of service and their satisfaction (Czepiel, 1990).

\section{Customer Perceived Value (CPV)}

Customer perceived value is "the difference between the prospective customer's evaluation of all the benefits and costs of an offering and the perceived alternatives" (Kotler \& Keller, 2016. Generally perceived value can be defined as the "the consumer's overall assessment of the utility of a product (or service) based on perceptions of what is received and what is given" (Zeithaml, 1988). According to the Kotler \& Keller, (2006), perception is "the process by which people select, organize and interpret information form a meaningful picture of the world". Past researchers widely used a perceived value definition for their researches as customers' assessment of the benefits that customers received and sacrifices that customers are incurring in choosing a specific product or service among available options in the market (Sanchez-Fernandez \& Iniesta-Bonilla, 2007; Chen \& Dubinsky, 2003).

When considering the past studies, there are several studies assessing the relationship between CPV and CS related to the service industry. Among them there are few studies concerning the complex models of CPV. Perceived value is influencing CS and repurchase intention of customers (Cronin et al., 2000). Petrick \& Backman (2002), proposed the scale (SERV-PERVAL) including five dimensions (perceived quality, monetary price, behavioural/ non-monetary price, perceived reputation and emotional response) to measure the perceived value. Perceived value is an significant predecessor of CS (Cronin et al., 2000) and past researchers have proposed the monetary price and perceived quality as key antecedents of CPV in tourism services (Duman \& Mattila, 2005). According to Richard (1996), perceived quality of restaurants can be defined as the customers' evaluation of intrinsic attributes as taste, food ingredients, nutritional values and overall food quality (Bellizzi et al., 1981). Customer assesses the quality related to intrinsic (colour, flavour, aroma and size of the products) and extrinsic factors (packaging, advertising, price and peer comments) (Collins \& Lindley, 2003). Perceived quality is a key element of perceived value while making customers satisfying towards products and services (Zeithaml, 1988). Sweeney \& Soutar (2001) defined the emotional response as "the utility derived from the feelings or affective states that a product has generated is part of overall perceived value". Therefore there is a direct association between customers' emotional response and their overall perceived value (Petrick, 2002). According to the study of Sweeney \& Soutar (2001) also proved that emotional responses having positive correlation with perceived value with empirical evidences. Price is the monetary value or money that customers are sacrificing to acquire the product or service (Zeithaml, 1988). Price is a key indicator of quality of the products and companies are reducing the prices to reduce the level of cost and vice versa (Zeithaml, 1988). Price is related to the self-esteem of people and if they have good economic condition, they prefer to consume high quality food (Petrick, 2002). Past researchers found that non-monetary or behavioural price also positively contributing towards the perceived quality and perceived value of the customers (Zeithaml, 1988). Zeithaml (1988) stated that nonmonetary price playing a moderating role in determining perceived value and it will lead to the overall satisfaction of customers through that. Association of restaurant image/reputation with CPV is a vital dimension of customer behaviour and eventually it will influence the customer loyalty towards the restaurants. Reputation will inspire the selecting decision of customers and it directly affected towards the customer-related outcomes (Kotler \& Fox, 1995). Good reputation or company image linked with delivering high value with products and services and it has strong correlation to offer the high quality service and products (MacMillan et al., 2005). Reputation of products and services can be considered as an important factor which is influencing customer perceived value (Zeithaml, 1988). 
Past scholar works have confirmed that CPV as a critical predictor on CS and their behavioural intentions (Andreassen \& Lindestad, 1998; Ryu et al., 2011). As Andreassen \& Lindestad, 1998 revealed, CPV was a significant element of CS and it is positively relate with CS in service industries. CPV had a direct positive relationship with CS in service industries (McDougall \& Levesque, 2000). Ryu et al. (2011) confirmed that restaurant image positively impacted CPV in casual restaurants and CPV significantly impacted on CS. Past researchers, Patterson \& Spreng (1997), assessed the role of CPV in customer experience and their behaviour in service sector and confirmed that CPV is significant and main antecedent of CS in service context.

\section{Customer Satisfaction (CS)}

There is a growing interest towards CS when measuring the company quality and forecasting future profits. According to the marketing literature satisfaction can be defined as customers' overall assessment about the acquisition and the usage experience of a good or service (Cronin \& Taylor, 1992). It is relating the final stage of consumer buying process and it is happen, when consumer is evaluating benefits gained through buying process (Oliver, 2014). Kotler \& Keller (2016) defined CS as “a person's feelings of pleasure or disappointment that result from comparing a product or service's perceived performance (or outcome) to expectations. CS is "the degree to which a product's perceived performance in providing value matches a customer's expectations" (Armstrong \& Kotler, 2003). According to the Yuan \& Jang (2008), when compared with the cost (time, money and effort) and obtained benefits, if customer recognized more benefits than the costs, satisfaction will occur. It is very important since it represents particular customer evaluations of the consumption experience associated with products or services (Cronin \& Taylor, 1992). In modern marketing practices, CS can be considered as a central concept. High level of CS resulting high financial performance by decreasing customer switching, enhancing customer loyalty, increasing organizational reputation and positive/ favourable word of mouth. By identifying that importance, researchers were tend to study on CS during past two decades (Srivastava, 2013).

\section{Customer (Tourist) Satisfaction in Hotel Industry and Restaurants}

In the satisfaction of tourists, hotels are contributing in a huge way since hotels can be considering as a second home for tourists who are living outside their homes. Therefore tourist satisfaction is depending on their perceptions on facilities and services offered by the hotels. Tourists' perception of hotel attributes can be consider as the level to which hotel facilities and services are significantly increasing tourists satisfaction during their stay at hotels (Wuest et al.,1996). Hotels are performing in highly competing industry since it suggests similar products and services which can be easily imitate by other rivals within the industry. According to the researches (Poon \& Low, 2005), quality and CS can be consider as best differentiation strategy which will generate competitive advantages over rivals. Therefore it is essential to recognize the level of customer satisfaction (Naumann, 1995). For the sustainable survival of the hotel, it should incorporate with organizational corporate culture. Customer-oriented organizations are able to achieve the objective of satisfying the existing customers than attracting new customers (Pizam \& Ellis, 1999).

Most of the researchers affirmed that, CS can be depended on quality of service since, improvement of service quality is leading to high satisfaction (Parasuraman et al., 1988; Ahrholdt, et al., 2017). However, with the single dimension, quality of the service cannot be measured (Manosalvas et al., 2019). In 1993 Fornell has developed this ACSI model by recognizing the antecedents and consequences of CS and the causal relationships between those factors and CS (Suleiman, 2012). According to the Chen (2012), basically it is including six factors in ACSI model; perceived quality, perceived value, consumer expectations, customer satisfaction, customer loyalty and customer complaint (Dani, 2014). 


\section{Research Methodology}

\section{Conceptual Framework and Hypothesis Development}

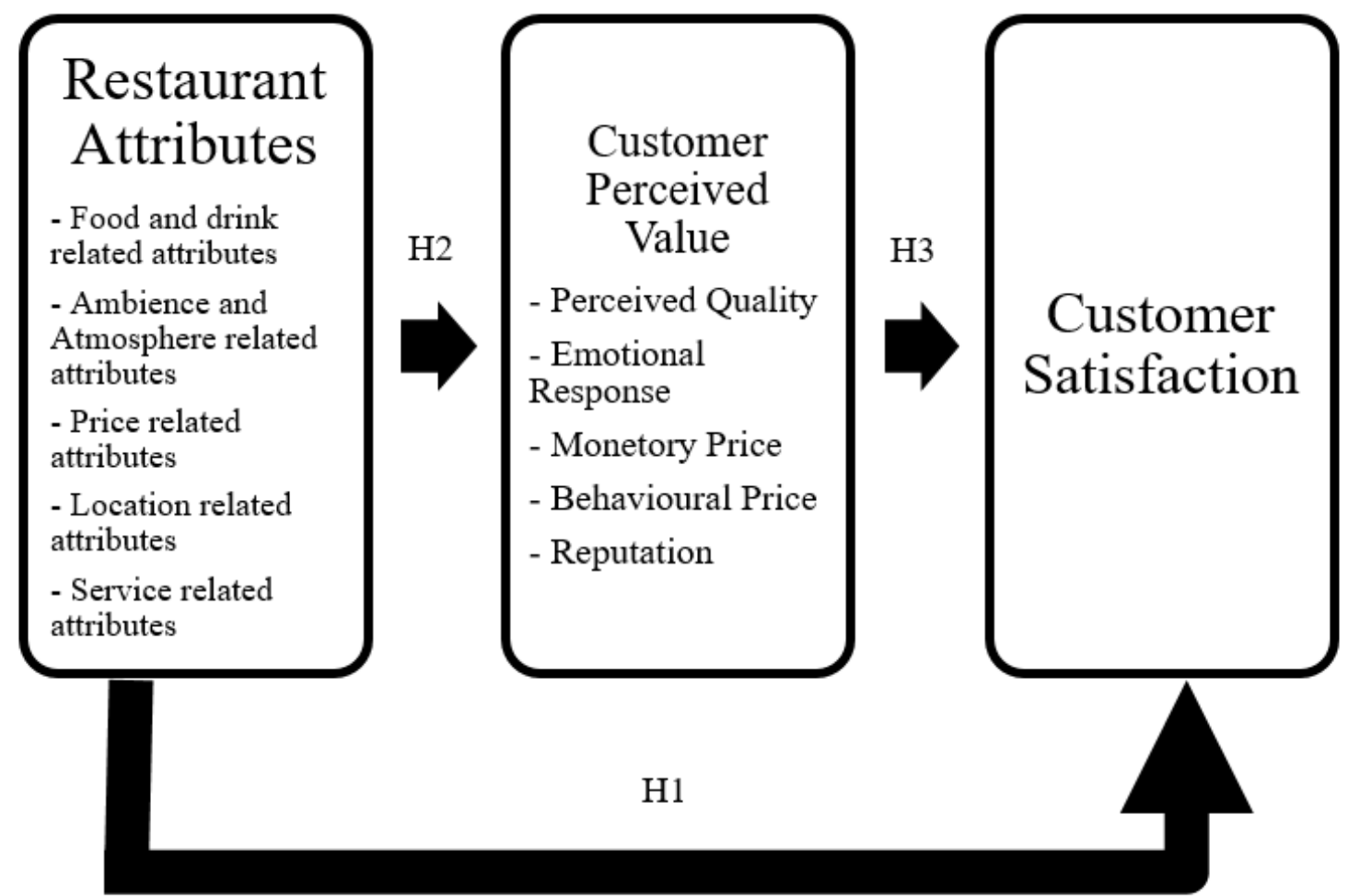

H4

Figure 1. Conceptual Framework

Based on the literature, researcher can suggest this model to test the relationship between most influential RA which has identified by conducting confirmatory factor analysis and CS. According to the figure 1, theoretical model has considered restaurant attributes as independent variable, customer satisfaction as dependent variable and customer perceived value as mediator variable.

- H1: There is a positive relationship between RA and CS

- H2: There is a positive relationship between RA and CPV

- H3: There is a positive relationship between CPV and CS

- H4: There is a positive relationship between RA and CS when mediated by CPV

\section{Population}

The study population comprises with the international tourists who are coming to coastal area in Sri Lanka to fulfill their dinning requirements.

\section{Sample}

Researcher selected the sample of 385 international tourists who are coming to the South coast, Sri Lanka to fulfil their dinning requirements. Since most of the tourists (83.2\%) visited Sri Lanka for the leisure purpose (SLTDA, 2019), mostly they are gathering to the leisure sites and coastal areas around the country. South coast is having the largest accommodation capacity (8,695 rooms) and highest occupancy rates (59.68) in tourist hotels in Sri Lanka during the 
last year 2019 (SLTDA, 2019). When considering foreign guest nights in tourism regions, south coast having highest foreign guest nights $(3,686,554)$ in graded accommodation establishments in year 2019 (SLTDA, 2019) representing the highest tourist demand for the area. As a result of a preliminary study, researcher has found that highest number of beach restaurants are located in Mirissa, Tangalle and Unawatuna when compared with other destinations in South coast, Sri Lanka. Therefore, researcher has considered three main areas in South coast as Mirissa, Tangalle and Unawatuna to cover all areas in South Coast as up to Galle and beyond Galle.

\section{Sampling Technique and Sample Size}

Sampling technique is non probabilistic technique and sample has selected by using convenient sampling technique since there is no exact number of tourists who are coming to these areas to fulfill their dinning requirements. Sample size has determined by using Cochran formula suggested by Cochran (1953), using 95\% confidence level and with the maximum error of 0.05 . Therefore, three hundred and eighty five (385) number of tourists has selected as sample from the selected areas.

\section{Data Collection Instrument}

In the current survey, primary data has collected through personal visits. Therefore, it has assured from participants about their readiness to participate in survey. Researcher has used self-administrated questionnaire and filled it from the right respondents for accurate results. At the end of initial screening, from 385 questionnaires 354 were completed and appropriately filled. The effective response for this study was $92 \%$.

\section{Data Analysis Method}

The researcher has entered all the collected data through questionnaire into SmartPLS 3.0 software (Ringle et al., 2015) to analyze data. To achieve the objectives of the study, confirmatory factor analysis and mediator analysis has used.

\section{Reliability and Validity Measures}

\begin{tabular}{|c|c|c|c|}
\hline & Cronbach's Alpha & CR & AVE \\
\hline CPV & 0.876 & 0.877 & 0.593 \\
\hline RA & 0.868 & 0.833 & 0.503 \\
\hline CS & 0.806 & 0.882 & 0.519 \\
\hline
\end{tabular}

Table 1. Reliability and Validity of the Data

Researcher has calculated Cronbach's Alpha values, Composite Reliability and Convergent Validity (AVE) values of each variable. According to the table 1 Cronbach's Alpha of all variables are meeting the least threshold level of 0.70 (Mihail \& Kloutsiniotis, 2016). As presented in above table 1 composite reliability coefficient can be seen from 0.833 to 0.882 of each latent constructs. As per the Bagozzi \& Yi (1988), all three composite reliability coefficient values are beyond the minimum adequate level of 0.70 . According to the results, it can be determined that adequate internal consistency reliability was established between variables (Hair et al., 2012). Validity has assessed by calculating a construct's convergent validity and discriminant validity. As per Hair et al., (2014) when each factor has more than 0.7 outer loadings and when each variables' average variance extracted (AVE) is 0.50 or higher, it can conclude that there is a validity among variables. 
Table 2. Discriminant Validity

\begin{tabular}{|c|c|c|c|}
\hline & CPV & CS & RA \\
\hline CPV & 0.770 & & \\
\hline CS & 0.621 & 0.720 & \\
\hline RA & 0.644 & 0.294 & 0.709 \\
\hline
\end{tabular}

Discriminant validity (DV) represents the degree of distinctive level of the construct from other constructs. Fornell \& Larcker's (1981) criterion was used to assess the DV of all variables in the model. Above table 2 is representing DV values in bold letters and correlation among each variables. As per the criterion, DV value is the square root of AVE of each variable. All DV values are greater than the correlations among variables, therefore according to the Fornell \& Larcker (1981) it can be suggested adequate DV in each variable.

\section{Data Analysis and Interpretation}

Table 3. Demographic Profile of the Respondents

\begin{tabular}{|c|c|c|c|}
\hline & & Frequency & Percent \\
\hline \multirow[t]{2}{*}{ Gender } & Male & 148 & $41.81 \%$ \\
\hline & Female & 206 & $59.19 \%$ \\
\hline \multirow[t]{6}{*}{ Age } & Below 20 years & 8 & $2.26 \%$ \\
\hline & 20 - 30 years & 150 & $42.38 \%$ \\
\hline & $31-40$ years & 110 & $31.07 \%$ \\
\hline & 41- 50 years & 45 & $12.71 \%$ \\
\hline & $51-60$ years & 33 & $9.322 \%$ \\
\hline & Above 60 years & 8 & $2.26 \%$ \\
\hline \multirow[t]{6}{*}{ Occupation } & Public Sector & 72 & 20.34 \\
\hline & Private Sector & 100 & 28.25 \\
\hline & Self- Employment & 75 & 21.19 \\
\hline & Semi Government & 14 & 3.95 \\
\hline & Professional & 52 & 14.69 \\
\hline & Other & 41 & 11.58 \\
\hline \multirow[t]{6}{*}{ Travel with } & Individual & 51 & $14.41 \%$ \\
\hline & Partner & 108 & $30.51 \%$ \\
\hline & Husband / Wife & 50 & $14.12 \%$ \\
\hline & Family & 38 & $10.73 \%$ \\
\hline & Friends & 95 & $26.84 \%$ \\
\hline & Travel Group & 12 & $3.39 \%$ \\
\hline
\end{tabular}

Hundred and forty eight (148- 41.81\%) male tourists and two hundred and six (206 - 59.19\%) female tourists were participated to the study. According to the collected data majority (hundred and fifty) of the tourists are under the age of 20-30 years and as a percentage it takes $42.38 \%$ from the whole sample. There $31.07 \%$ (hundred and ten) tourists from 31-40 years. Few number of tourists (eight) are under the category of below 20 years as well as above 60 years. When considering the occupation level of the respondents, most of them (hundred) $(28.25 \%)$ are working in a private sector, and $21.19 \%$ (seventy-five) tourists are working in a semi-government as well. 20.34\% (seventy-two) are working in a public sector and $14.59 \%$ (fifty-two) are professionals. Most of the tourists (108-30.51\%) were travelled 
with their partners. $26.84 \%$ (ninety-five) travelled with their friends. When it compares with the age highest number of tourists are under 20-40 years. It means they have mostly travelled with their partners as well as with their friends. Also, as the new trend of tourism fifty-one (14.41\%) solo travelers were there. Most of the tourists who travel with travel groups are not allow to stay at the beach and go to the restaurants as they prefer since they have participated in a scheduled tour by the travel agent. By proving that least number of tourists, (twelve) $3.39 \%$ who travelled with travel group have responded to the study.

\section{Confirmatory Factor Analysis}

To identify the factors which are influencing restaurant attributes in beach restaurants, researcher has conducted confirmatory factor analysis.

Table 4. Factor Loadings of All Indicators

\begin{tabular}{|c|c|c|c|}
\hline & CPV & $\mathrm{CS}$ & RA \\
\hline PRQ1 & 0.842 & & \\
\hline PRQ2 & 0.560 & & \\
\hline PRQ3 & 0.768 & & \\
\hline PRQ4 & 0.603 & & \\
\hline PRQ5 & 0.519 & & \\
\hline PRQ6 & 0.823 & & \\
\hline PRQ7 & 0.720 & & \\
\hline PER1 & 0.742 & & \\
\hline PER2 & 0.632 & & \\
\hline PER3 & 0.68 & & \\
\hline PER4 & 0.611 & & \\
\hline PER5 & 0.561 & & \\
\hline PMP1 & 0.642 & & \\
\hline PMP2 & 0.540 & & \\
\hline PMP3 & 0.597 & & \\
\hline PMP4 & 0.617 & & \\
\hline BP1 & 0.572 & & \\
\hline BP2 & 0.668 & & \\
\hline BP3 & 0.63 & & \\
\hline BP4 & 0.687 & & \\
\hline REP1 & 0.834 & & \\
\hline REP2 & 0.826 & & \\
\hline REP3 & 0.839 & & \\
\hline $\mathrm{CS} 1$ & & 0.785 & \\
\hline $\mathrm{CS} 2$ & & 0.811 & \\
\hline $\mathrm{CS} 3$ & & 0.647 & \\
\hline $\mathrm{CS} 4$ & & 0.683 & \\
\hline CS5 & & 0.287 & \\
\hline CS6 & & 0.642 & \\
\hline CS7 & & 0.658 & \\
\hline
\end{tabular}




\begin{tabular}{|c|c|c|}
\hline $\mathrm{C} 8$ & 0.792 & \\
\hline $\mathrm{F} 1$ & & 0.782 \\
\hline $\mathrm{F} 2$ & & 0.607 \\
\hline F3 & & 0.051 \\
\hline F4 & & 0.165 \\
\hline F5 & & 0.618 \\
\hline F6 & & 0.638 \\
\hline L1 & & 0.793 \\
\hline L2 & & 0.353 \\
\hline L3 & & 0.613 \\
\hline L4 & & 0.639 \\
\hline L5 & & 0.557 \\
\hline P1 & & 0.551 \\
\hline P2 & & 0.665 \\
\hline P3 & & 0.563 \\
\hline S1 & & 0.856 \\
\hline S2 & & 0.817 \\
\hline S3 & & 0.626 \\
\hline S4 & & 0.618 \\
\hline S5 & & 0.676 \\
\hline S6 & & 0.367 \\
\hline S7 & & 0.537 \\
\hline A1 & & 0.616 \\
\hline A 2 & & 0.241 \\
\hline A3 & & 0.462 \\
\hline A4 & & 0.571 \\
\hline A5 & & 0.563 \\
\hline A6 & & 0.671 \\
\hline A7 & & 0.526 \\
\hline
\end{tabular}

*** Correlation is significant at 0.05 level (2-tailed)

As per table 3, factor (outer) loadings of each indicator have taken to measure the reliability of the indicators. Some outer loadings were less than 0.5 (mentioned in bold) and it has taken indicators which have outer loadings more than 0.5 for PLS measurement model as recommended by Barclay et al (1995). By following that rule of thumb, researcher has removed some indicators (A2, A3, F3, F4, L2, S6 and CS5) and all other indicators which are met the criteria have used for the further analysis of the model.

\section{Mediator Impact Analysis}

To assess the impact of Customer Perceived Value in the relationship between Restaurant Attributes and Customer Satisfaction, the researcher followed the bootstrapping techniques to assess the full PLS structural model in simple mediation models when estimating indirect effects as recommended by Hair at el (2014). Firstly, to assess the hypotheses 1, researcher considered the direct effect between RA and CS, without considering mediator impact of CPV. 
Table 5. Path Coefficients - Direct Effect

\begin{tabular}{|c|c|c|c|}
\hline & Original Sample & T Statistics & P Values \\
\hline RA -> CS & 0.223 & 0.884 & 0.377 \\
\hline RA -> CPV & 0.894 & 37.258 & 0.000 \\
\hline CPV -> CS & 0.569 & 8.492 & 0.000 \\
\hline
\end{tabular}

Above table 5 summarizes the results which explains the direct relationships among independent, dependent and mediator variables. Independent variable, RA has a direct impact on CS. However, $t$-statistics value (0.884) is less than 1.96 , and this effect is not statistically significant (p-value 0.377 ) at 0.05 level. Thus, $\mathrm{H} 1$ is not significant at 0.05 statistical significant level and it is rejected. Moreover, H0, null hypothesis has accepted. Independent variable, RA has a direct statistical effect (0.894) on mediator variable, CPV and t-statistics value (37.258) is higher than 1.96. Since p-value (0.000) of these values are less than 0.05 statistical significance level this effect can be considered as statistically significant. Therefore $\mathrm{H} 2$ can be accepted. Mediator variable, $\mathrm{CPV}$ has a direct statistical effect $(0.569)$ on dependent variable, CS and t-statistics value (8.492) is higher than 1.96. The p-value (0.000) also less than 0.05 statistical significant level and this effect is statistically significant. Therefore $\mathrm{H} 3$ can be accepted.

Total indirect effects between variables are shown below as the table 6. An indirect effect between independent variable, RA and dependent variable, CS. Is 0.509 . The t-statistics value is 8.079 and it is higher than 1.96 . H4 can be accepted, since both values are statistically significant at 0.05 significance level. There are no indirect effect between RA and CPV as well as CPV and CS.

Table 6. Total Indirect Effects

\begin{tabular}{|c|c|c|c|}
\hline & Original Sample & T Statistics & P Values \\
\hline RA $>$ CS & 0.509 & 8.079 & 0.000 \\
\hline RA $>$ CPV & & & \\
\hline CPV $>$ CS & & & \\
\hline
\end{tabular}

*** Correlation is significant at the 0.05 level (2-tailed)

Total effects between variables are shown in table 7. Even though there is no indirect effect between RA and CPV as well as CPV and CS. Therefore, total effects should equal to direct effect values. However, there is a total effect of 0.732 existing between independent (RA) and Dependent (CS) variables. All the t-values are higher than 1.96 and all the total effects are statistically significant at 0.05 level.

Table 7. Total Effects

\begin{tabular}{|c|c|c|c|}
\hline & Original Sample & T Statistics & P Values \\
\hline RA -> CS & 0.732 & 8.47 & 0.000 \\
\hline RA -> CPV & 0.894 & 37.258 & 0.000 \\
\hline CPV -> CS & 0.569 & 8.492 & 0.000 \\
\hline
\end{tabular}

*** Correlation is significant at the 0.05 level (2-tailed) 
To prove the mediating effect among variables, researcher has used Smart PLS bootstrapping technique with 1000 samples which are drawn randomly, with replacement at the 0.05 statistical significance level. According to the table 8 below, it has verified three different levels of mediating effects.

Table 8. Mediating role of Customer Perceived Value

\begin{tabular}{|c|c|c|c|c|c|}
\hline & $\begin{array}{c}\text { Direct Effect } \\
(\mathrm{t}-\text {-value })\end{array}$ & $\begin{array}{c}\text { Indirect Effect } \\
(\mathrm{t} \text {-value })\end{array}$ & $\begin{array}{c}\text { Total Effect } \\
\text { (t-value) }\end{array}$ & Effects & Result \\
\hline RA ->CPV-> CS & $\begin{array}{c}0.223 \\
(0.884)\end{array}$ & $\begin{array}{c}0.509 \\
(8.079)\end{array}$ & $\begin{array}{c}0.732 \\
(8.47)\end{array}$ & Full Mediation & H4 supported \\
\hline
\end{tabular}

*** Correlation is significant at the 0.05 level (2-tailed)

According to the results, it supports H4 and CPV fully mediates the association between RA and CS. According to Hair at el., (2016) if the direct effect between independent and dependent variables without mediator is not significant and indirect effect between independent variable, RA and dependent variable, CS through mediator, CPV is significant, it can conclude that, there is a full mediation effect of the mediator between the independent and dependent variables.

I. The direct effect is not statistically significant.

II. The indirect effect is statistically significant.--> Full mediation

Therefore it can be determined that there is a full mediation of CPV between the relationship of RA and CS.

\section{Discussion and Conclusion}

In the business world, CS is playing a major role and studies on CS have continuously conducting by the researchers. Past researchers have significantly contributed to determining the RA affecting CPV value and tourist satisfaction (Yüksel \& Yüksel, 2002). However, tourists who visited and had meals at beach restaurants in South coast, Sri Lanka were rarely the respondents of these past studies. Therefore, this study has conceptualized the model by using international tourists who visited South coast, Sri Lanka throughout the study period. Moreover, the findings of the research will contribute to the destination managers, restaurant owners and marketing managers to realize the significance of tourist (customer) satisfaction in tourism businesses.

- To identify the factors which are influencing restaurant attributes in beach restaurants

Through the past researches, researcher has identified different factors which can be considered as RA which are influencing CPV and CS. Researcher confirmed those factors with different indicators by conducting confirmatory factor analysis. As discussed in previous chapters, it has identified five main RA as Food and Drink related attributes (FDA), Ambience and Atmosphere related attributes (AAA), Price related attributes (PA), Location related attributes (LA) and Service related attributes (SA).

Variety of menu items, fresh and good quality food ingredients, great quality and taste of foods and availability of range of beverages determined the food and drink related attributes. Food presenting style and size of food portion has not much rated by tourists to determine the food and drink related attributes. Tourists were ranked availability of internal displays and wall décor in restaurants, attractive and comfortable atmosphere to dine, availability of attractive music and dancing, availability of attractive aroma and availability of good quality dinning equipment to determine ambience and atmosphere related attributes. However, they did not ranked availability of comfortable lighting and temperature and availability of enough seating space to determine the ambience and atmosphere related attributes. Comparing prices of different restaurants before select the meal, if quality is good, do not consider about prices, and consider high-priced restaurants as good restaurants were ranked by tourists as indicators to determine price related attributes. Attractive location, convenience place for every customer to meet up, suitable place as entertainment area 
and availability of public transportation marked as indicators to determine location related attributes. Availability of enough parking facilities has much ranked by customers to determine location related attributes. Employees' friendliness and willingness to help, employee's knowledge, their efficiency and high quality service, their neatness and clean appearance, waiters' personal attention and serving meals at the promised time marked as dimensions of service related attributes and customers not much ranked waiters' attentiveness to customers' needs to determine the service related attributes. Accordingly, respondents ranked 22 dimensions to determine RA to influence the CPV and CS in beach restaurants. Therefore restaurant owners should improve the effectiveness of these attributes to meet the customer's expectation up to satisfactory level.

- To assess the impact of Customer Perceived Value in the relationship between Restaurant Attributes and Customer Satisfaction

$\mathrm{RA}$ is having strong positive relationship $(0.894, \mathrm{t}$ value $=37.258, \mathrm{p}$ value $=0.000)$ with the mediator, $\mathrm{CPV}$ and CPV is having moderate positive relationship $(0.569, \mathrm{t}$ value $=8.492, \mathrm{p}$ value $=0.000)$ with CS. Therefore, the results are indicating that the RA were significant determinants of CPV. This is positively supported by the past research with the argument that, RA were inter-related with CPV (Longart at el., 2018).

Moreover, CPV was significant determinant of CS and it is creating strong and direct impact on CS. Perceived restaurant quality, Perceived emotional response of customers, Perceived monetary price, Perceived behavioural price and Perceived reputation are the determinants of CPV and all these factors are having direct impact towards CPV. According to the results it has in lined with past researches when considering the relationship between CPV and CS (Hettiarachchia \& Lakmal, 2018). Therefore, CPV has found as most important factor in determining CS (Ali at el., 2015). Therefore, results are revealing that, there is a full mediation impact of CPV between the relationship of RA and CS with the total mediatory effect of 0.732 ( $\mathrm{t}$ value $=8.47, \mathrm{p}$ value $=0.000$ ). These results are positively inconsistent with past researches (Ryu et al., 2011). Moreover, not only in the restaurants, in other service industries also, CPV is playing a mediator role between attributes such as service quality and CS (Cronin et al., 2000).

\section{Theoretical Implications}

The study examined different RA in customers' experience and satisfaction. Specifically this is considering food and drink related attributes (food quality, food and beverage varieties in menu, freshness of food ingredients, food taste); ambience and atmosphere related attributes (decorations, physical environment, music, colours); price related attributes (menu price); location related attributes (easy accessibility, availability of public transportation) and service related attributes (employees' knowledge, prompt service, service quality, responsiveness) in determining CPV and CS. Therefore, this study represent more comprehensive analysis of customer experience such as CPV and CS through diverse RA. Secondly, current study evaluates the importance of identified RA in beach restaurants in shaping customer experience. However, previous studies have mainly focused on the attribute performance (Jang et al., 2012) and the current study is confirming the significance of RA by identifying the fundamental role of RA in determining customer experience at beach restaurants. According to the findings, service and food and drink related attributes are most significant attributes which are influencing customer experience in beach restaurants. Thirdly, this study is identifying consequences as customer's values such as perceived value (Perceived restaurant quality, Perceived emotional response of customers, Perceived monetary price, Perceived behavioral price and Perceived reputation) and ultimate customer experience (satisfaction, dissatisfaction, excitement, delightfulness) that they can achieve through these attributes. This study is utilizing proper method to identify most important attributes which are gaining those values and benefits for the customers in restaurant settings. Moreover, this study is contributing existing literature on RA in evaluating the relationship between CPV and CS.

\section{Marketing and Managerial Implications}

This study has suggested marketing and managerial implications for restaurateurs to implement in their businesses to obtain highest results. Restaurateurs are required to understand the importance of RA to identify the value of each attribute to enhance the CPV. Since the service and food and drink related attributes are serving high contribution to 
enhance the value of restaurants and CS, owners are required to enhance service quality and food and drink related attributes in restaurant industry (Namkung \& Jang, 2007). Because of these factors, customer behavioral intentions are enhancing and they will spread encouraging word of mouth about the restaurant among others. Therefore maintaining high quality service and high quality food than achieving cost advantages will establish positive image towards beach restaurants by making it more unique and differentiate among other competitive restaurants.

However, results discovered that, maintaining quality of service and food is not enough to influence customer experiences. Therefore, physical environment and atmosphere and also location should be maintained to attract more customers towards the restaurants by keeping the environment clean and appealing, promoting the beach concept more at the restaurants and applying the theme into the furniture, employee dress codes, and meal presentation. Owners should get maximum benefit of the location of these restaurants since South coast is having eye appealing beach and coastal line which can attract more customers towards the restaurants. All these factors can enhance the perceived value of customers and their experience. Restaurant managers are required to utilize these valuable assets and properly plan, change and control the physical environment (background colours, drawings can be matched with sea theme, background music, matching furniture, dress code of employees) of these restaurants to maintain distinct and unique environment to differentiate the place among rivals.

Apart from that customer service should enhance by maintaining good hygienic conditions and safety in the food and environment. When considering about the employees such as food servers, restaurant owners and guides for surfing and other beach related activities they should have proper knowledge about the environment and near attractions. Most of the employees are from near villages and cities and they are not much focusing on dress code and neatness of their dresses. Moreover, they don't have proper standards of serving foods and proper English knowledge to communicate. However, beach restaurants are maintaining their own culture and they are getting high demand for that authentic experiences. Therefore, they should maintain the culture carefully and try to attract more customers towards the concept.

These restaurants are providing surfing facilities, snorkeling, water diving, arranging whale watching tours, coordinating excursions, and cooking classes for tourists and entertainment facilities such as DJ parties. Restaurateurs should enhance the variety of these kind of services to attract more customers and keep them for more hours with the restaurants. These restaurants are not considering fast food restaurants and it is an opportunity for beach restaurants since when customers are visiting the restaurants during morning time, they will stay at the same place until evening or night while engaging different beach related sports activities, reading books, resting, relaxation, consuming food and beverages, sea bathing and sun bathing. Therefore, providing variety of products and services will enhance the spending time of customers, their experience, and their satisfaction and ultimately increase sales revenue for the business.

For restaurant owners, the results are relating to the mediating role of CPV reveal that achieving CS not only based on the restaurants' ability to achieve CPV, however to create a positive image for the beach restaurants. Therefore the association between restaurant image, CPV and CS should strengthen customer behavior to enhance the revisit intention towards the place and favorably recommend the place to others (Word of mouth). Moreover, they should critically focus on all above factors to enhance the CPV since it is playing a major role in the link between RA and CS. It is one of the most valuable factor for service sector to create benchmark and it is required to monitor the performance of employees as well as feedback of the customers to become effective business.

\section{Limitations and Future Research Directions}

As every study, current study also having practical limitations. These limitations be able to address in future studies. Basically, this study has conducted for beach restaurants in South coast in Sri Lanka and it is difficult to generalize the results for all types of restaurants and all Sri Lankan coastal areas as Northern and Eastern areas. Customer motives and influences for their satisfaction may be differed through different restaurant types as fast food restaurants are attracting customers who are valuing fast service for low cost (Ponnam \& Balaji, 2014). Therefore future studies can focus on different types of restaurants for their studies and they can compare the results with each other. Secondly, 
sample size is not comparatively larger with the number of customers who are attracting towards South coast. There can be errors in generalizing the results for whole population. However, sample size is in lining with statistical requirements when conducting convenience sampling technique to select the sample and it is sufficient for the analysis. Thirdly, scope of the research study was restricted to analyses the relationship between RA with CPV and CS. However, there is a potential future researchable areas such as examining the association between these restaurants and behavioural intentions of customers such as return intention and readiness to spread encouraging word of mouth among others. This study has collected data from customers (tourists) only. However, for the future researches, it can be suggested to collect data from service providers' aspect as well to get more balance results from both two aspects.

\section{References}

Ahrholdt, D. C., Gudergan, S. P., \& Ringle, C. M. (2017). Enhancing service loyalty: The roles of delight, satisfaction, and service quality. Journal of Travel Research, 56(4), 436-450.

Ali, R., Leifu, G., YasirRafiq, M., \& Hassan, M. (2015). Role of perceived value, customer expectation, corporate image and perceived service quality on the CS. Journal of Applied Business Research (JABR), 31(4), 1425-1436.

AroraAnderson, E. W., \& Sullivan, M. W. (1993). The antecedents and consequences of CS for firms. Marketing science, 12(2), 125-143.

Anderson, E. W., Fornell, C., \& Rust, R. T. (1997). Customer satisfaction, productivity, and profitability: Differences between goods and services. Marketing science, 16(2), 129-145.

Andreassen, T. W., \& Lindestad, B. (1998). Customer loyalty and complex services: The impact of corporate image on quality, customer satisfaction and loyalty for customers with varying degrees of service expertise. Int. J. Serv. Ind. Manage., 9(1): 7-23.

Armstrong, G., \& Kotler, P. (2003). Marketing: An Introduction, New Jersey: Prentice Hall

Baek, S. H., Ham, S., \& Yang, I. S. (2006). A cross-cultural comparison of fast food restaurant selection criteria between Korean and Filipino college students. International Journal of Hospitality Management, 25(4), 683-698.

Bagozzi, R. P., \& Yi, Y. (1988). On the evaluation of structural equation models. Journal of the academy of marketing science, 16(1), 74-94.

Barclay, D., Higgins, C., \& Thompson, R. (1995). The partial least squares (PLS) approach to casual modeling: personal computer adoption and use as an Illustration.

Barsky, J., \& Nash, L. (2006). Companies update loyalty programs, increase effectiveness. Hotel \& Motel Management, 22(11), 28-29.

Bellizzi, Joseph A., Krueckeberg, Harry F., Hamilton, John R., \& Martin, Warren S. (1981). Consumer Research, 15, $473-481$

Buultjens, J. W., Ratnayake, I., \& Gnanapala, W. A. C. (2016). Post-Conflict tourism development in Sri Lanka: implications for building resilience. Current Issues in Tourism, 19(4), 355-372.

Chen, L. (2012). Developing Hong Kong tourist satisfaction index using Bayesian structural equation modeling approach.

Chen, P. T., \& Hu, H. H. (2010). The effect of relational benefits on perceived value in relation to customer loyalty: An empirical study in the Australian coffee outlets industry. International journal of hospitality management, 29(3), 405-412.

Chen, Z. \& Dubinsky, A. J. (2003). A conceptual model of perceived customer value in e-commerce: A preliminary investigation. Psychology \& Marketing, 20 (4), 323-347.

Choi, T. Y., \& Chu, R. (2001). Determinants of hotel guests' satisfaction and repeat patronage in the Hong Kong hotel industry. International Journal of Hospitality Management, 20(3), 277-297.

Clark, M.A., \& Wood, R.C. (1999). Consumer loyalty in the restaurant industry: A preliminary exploration of the issues. British Food Journal, 101 (4), 317-326.

Cochran, W.G. (1953). Sampling Techniques. New York: John Wiley \& Sons.

Collins-Dodd, C., \& Lindley, T. (2003). Store brands and retail differentiation: the influence of store image and store brand attitude on store own brand perceptions. Journal of Retailing and consumer services, 10(6), 345-352. 
Cretu, A.E. and Brodie, R.J. (2007), "The influence of brand image and company reputation where manufacturers market to small firms: a customer value perspective", Industrial Marketing Management, Vol. 36 No. 2, pp. 230-40.

Cronin Jr, J. J., Brady, M. K., \& Hult, G. T. M. (2000). Assessing the effects of quality, value, and CS on consumer behavioral intentions in service environments. Journal of retailing, 76(2), 193-218.

Czepiel, J. A. (1990). Service encounters and service relationships: implications for research. Journal of business research, 20(1), 13-21.

Dani, V. (2014). Measuring CS for F\&B chains in Pune using ACSI Model. Procedia-social and behavioral sciences, 133, 465-472.

Dhurup, M., Mafini, C. and Malan, J. (2013) Consumer Responses to Salient Image Attributes in Restaurant Selection in Southern Gauteng, South Africa. Mediterranean Journal of Social Sciences, 4 (3), 283-294

Duman, T., \& Mattila, A. S. (2005). The role of affective factors on perceived cruise vacation value. Tourism management, 26(3), 311-323.

Fornell, C., \& Larcker, D. F. (1981). Evaluating structural equation models with unobservable variables and measurement error. Journal of marketing research, 18(1), 39-50.

Fernando, S., Bandara, J. S., \& Smith, C. (2013). Regaining missed opportunities: the role of tourism in post-war development in Sri Lanka. Asia Pacific Journal of Tourism Research, 18(7), 685-711.

Haghighi, M., Dorosti, A., Rahnama, A., \& Hoseinpour, A. (2012). Evaluation of factors affecting customer loyalty in the restaurant industry. African Journal of Business Management, 6(14), 5039-5046.

Hair, J. F., Sarstedt, M., Hopkins, L., \& Kuppelwieser, V. G. (2014). Partial least squares structural equation modeling (PLSSEM): An emerging tool in business research. European Business Review, 26(2), 106-121.

Hair, J. F., Sarstedt, M., Ringle, C. M., \& Mena, J. A. (2012). An assessment of the use of partial least squares structural equation modeling in marketing research. Journal of the Academy of Marketing Science, 40, 414-433.

Hair, Joe \& Hult, G. Tomas M. \& Ringle, Christian \& Sarstedt, Marko. (2016). A Primer on Partial Least Squares Structural Equation Modeling (PLS-SEM), 2nd edition.

Han, J. S., \& Hyun, K. S. (2009). The effect of family restaurants customer value on satisfaction and behavior intention: focused on university student in Seoul. Korean Journal of Hospitality Administration, 18(1), 135-150.

Hettiarachchia, W. N., \& Lakmal, H. M. A. (2018). The Impact of Perceived Value on Satisfaction of Adventure Tourists: With Special Reference to Sri Lankan Domestic Tourists.

Howlett, E. A., Burton, S., Bates, K., \& Huggins, K. (2009). Coming to a restaurant near you? Potential consumer responses to nutrition information disclosure on menus. Journal of Consumer Research, 36(3), 494-503.

Jang, S. S., Ha, J., \& Park, K. (2012). Effects of ethnic authenticity: Investigating Korean restaurant customers in the US. International Journal of Hospitality Management, 31(3), 990-1003.

Jang, S.C., \& Ha, J. (2009). Perceived values, satisfaction, and behavioral intentions: The role of familiarity in Korean restaurants. International Journal of Hospitality Management, 1 (3), 227-35.

Jang, Y. J., Kim, W. G., \& Bonn, M. A. (2011). Generation Y consumers' selection attributes and behavioral intentions concerning green restaurants. International Journal of Hospitality Management, 30(4), 803-811.

Kivela, J.J., Inbakaran, R. and Reece, J. (1999) Consumer research in the restaurant environment, Part 1: A conceptual model of dining satisfaction and return patronage. International Journal of Contemporary Hospitality Management, 11 (5), 205-222

Kotler, P., \& Fox, K. F. (1995). Strategic marketing for educational institutions. Prentice Hall.

Kotler, P., \& Keller, K. L. (2006). Marketing Management Twelve Edition.

Kotler, P., \& Keller, K. L. (2016). Marketing management. Global ed. Harlow, England: Pearson Education Limited.

Lai, T. W. (2002). Promoting sustainable tourism in Sri Lanka. Linking green productivity to ecotourism: Experiences in the Asia-Pacific region, 208-214.

Liu, Y., \& Jang, S. S. (2009). Perceptions of Chinese restaurants in the US: what affects CS and behavioral intentions?. International Journal of Hospitality Management, 28(3), 338-348.

Longart, P., Wickens, E., \& Bakir, A. (2018). An investigation into RA: A basis for a typology. International Journal of Hospitality \& Tourism Administration, 19(1), 95-123. 
MacMillan, K., Money, K., Downing, S., \& Hillenbrand, C. (2005). Reputation in relationships: measuring experiences, emotions and behaviors. Corporate Reputation Review, 8(3), 214-232.

Manosalvas, C., Manosalvas, L., Reyes, M., \& Paredes, L. (2019, August 22-24). Evaluation of CS with restaurant services through the ACSI Mode. ICBBD 2019: Tokyo University of Science, Tokyo, Japan.

McDougall, G. H. G., \& Levesque, T. (2000). Customer satisfaction with service: putting perceived value into the equation. J. Serv. Mark.,14(5): 392-410

Mihail, D. M., \& Kloutsiniotis, P. V. (2016). The effects of high-performance work systems on hospital employees' work-related well-being: Evidence from Greece. European Management Journal, 34(4), 424-438.

Namkung, Y. and Jang, S.S. (2008) Are highly satisfied restaurant customers really different? A quality perception perspective. International Journal of Contemporary Hospitality Management, 20(2), 142-155

Naumann, E., \& Giel, K. (1995). CS measurement and management: Using the voice of the customer. Van Nostrand Reinhold.

Oliver, R. L. (2014). Satisfaction: A behavioral perspective on the consumer: A behavioral perspective on the consumer. Routledge.

Omar, M. S., Ariffin, H. F., \& Ahmad, R. (2014). Factors affecting customers' satisfaction in Arabic restaurants. International Journal of Administration and Governance, 1(4), 1-8.

Parasuraman, A., Valarie Zeithaml, and Leonard Berry (1985), "A Conceptual Model of Service Quality and Its Implications for Future Research,” Journal of Marketing, 49 (Fall), 41-50

Parasuraman, A., Zeithaml, V.A., Berry, L.L. (1988) SERVQUAL: a multiple-item scale for measuring consumer perceptions of service quality, Journal of Retailing, 64(1), 12-40

Patterson, P. G., \& Spreng, R. A. (1997). Modeling the Relationship between Perceived Value, Satisfaction and Repurchase Intentions in a Business-to-Business, Services Context: An Empirical Examination. Int. J. Serv. Ind. Manage., 8(5): 414-434.

Petrick, J. F., \& Backman, S. J. (2002). An examination of the construct of perceived value for the prediction of golf travelers' intentions to revisit. Journal of travel research, 41(1), 38-45.

Petrick, James F. (2002). Development of a multi-dimensional scale for measuring the perceived value of services. Journal of Leisure Research, 34 (2), 119-134.

Pizam, A., \& Ellis, T. (1999). CS and its measurement in hospitality enterprises. International journal of contemporary hospitality management.

Ponnam, A., \& Balaji, M. S. (2014). Matching visitation-motives and RA in casual dining restaurants. International Journal of Hospitality Management, 37, 47-57.

Poon, W. C., \& Low, K. L. T. (2005). Are travellers satisfied with Malaysian hotels?. International Journal of Contemporary Hospitality Management.

Ringle, C. M., Wende, S., \& Becker, J.-M. (2015). Smartpls 3. Bonningstedt: SmartPLS. Retrieved from http://smartpls.com.

Ryu, K., Lee, H.R., \& Kim, W. G. (2011). The influence of the quality of physical environment, food, and service on restaurant image, CS, and behavioral intentions. International Journal of Contemporary Hospitality Management, 24 (2), 200-223.

Sánchez-Fernández, R., \& Iniesta-Bonillo, M. Á. (2007). The concept of perceived value: a systematic review of the research. Marketing theory, 7(4), 427-451.

Sri Lanka Tourism Development Authority. (2019), “Annual Statistical Report - 2019”, [pdf] Available at https://sitda.gov.lk/storage/common_media/AAnnual\%20Statistical\%20Report\%20new\%202109\%20Word388914421 5.pdf [Accessed 30th July 2020.]

Srivastava, S. (2013). A Study of the Impact of Customer Care Services on CS of Mobile Phone Subscribers of UP East Circle.

Su, A. Y. L. (2004). Customer satisfaction measurement practice in Taiwan hotels. International Journal of Hospitality Management, 23(4), 397-408.

Suleiman, A. M. (2012). An application of the American CS Index (ACSI) in the Jordanian mobile phone sector. The TQM Journal. 
Sulek, J. M., \& Hensley, R. L. (2004). The relative importance of food, atmosphere, and fairness of wait: The case of a full-service restaurant. Cornell Hotel and Restaurant Administration Quarterly, 45(3), 235-247.

Sweeney, J. C., \& Soutar, G. N. (2001). Consumer perceived value: The development of a multiple item scale. Journal of retailing, 77(2), 203-220.

Wade, D. (2006). Successful restaurant management: From vision to execution. Delmar: Cengage Learning

Walker, J.R. (2014) Exploring the Hospitality Industry, 2nd edition. Harlow: Pearson.

Wall, E. A., \& Berry, L. L. (2007). The combined effects of the physical environment and employee behavior on customer perception of restaurant service quality. Cornell hotel and restaurant administration quarterly, 48(1), 59-69.

Wansink, B., Van Ittersum, K., \& Painter, J. E. (2005). How descriptive food names bias sensory perceptions in restaurants. Food quality and preference, 16(5), 393-400.

Wuest, B. E., Tas, R. F., \& Emenheiser, D. A. (1996). What do mature travelers perceive as important hotel/motel customer services?. Hospitality Research Journal, 20(2), 77-93.

Yuan, J., \& Jang, S. (2008). The effects of quality and satisfaction on awareness and behavioral intentions: Exploring the role of a wine festival. Journal of Travel Research, 46(3), 279-288.

Yüksel, A., \& Yüksel, F. (2002). Measurement of tourist satisfaction with restaurant services: A segment-based approach. Journal of vacation marketing, 9(1), 52-68.

Zeithaml, V. A. (1988). Consumer perceptions of price, quality, and value: a means-end model and synthesis of evidence. Journal of marketing, 52(3), 2-22.

Zeithaml, V. A., Berry, L. L., \& Parasuraman, A. (1993). The nature and determinants of customer expectations of service. Journal of the academy of Marketing Science, 21(1), 1-12. 